Abd El-Aziz S. Fouda*, Ayman Y. El-Khateeb ${ }^{2}$, Hesham H. El-Zhery ${ }^{3}$, Mohamed Fakih ${ }^{4}$

${ }^{1}$ El-Mansoura University, Department of Chemistry, Faculty of Science, El-Mansoura, Egypt, ${ }^{2}$ Mansoura University, Department of Agric. Chemistry, Faculty of Agriculture, Mansoura, Egypt, ${ }^{3}$ Umm Al-Qura University, Health Science College at Al Leith, KSA, Egypt, ${ }^{4}$ Lab manager in Talkha sanitation plant, water and wastewater company, Daqahlia, Egypt
Scientific paper

ISSN 0351-9465, E-ISSN 2466-2585

UDC:620.193.4.8:669.112.5

Doi:10.5937/ZasMat1604583F

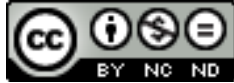

Zastita Materijala 57 (4)

583 - $596(2016)$

\title{
The role of aqueous ocimum basilicum extract for monitoring the corrosion inhibition of carbon steel used in sanitation plants and its effect on Escherichia coli
}

\begin{abstract}
The inhibitive effect of aqueous plant extract of Ocimum Basilicum was tested as green corrosion extract for $\mathrm{CS}(\mathrm{CS})$ in $3.5 \% \mathrm{NaCl}$ and $16 \mathrm{ppm} \mathrm{Na} \mathrm{Na}_{2} \mathrm{~S}$. It has excellent inhibition efficiency (\% P) of about $88 \%$ provided by weight loss, potentiodynamic polarization, electrochemical impedance spectroscopy (EIS), and electrochemical frequency modulation (EFM) measurements. The increase of the extract concentration leads to increase in the $\% P$. The adsorption of the extract on the CS surface obeys Langmuir adsorption isotherm with physical adsorption on the metal surface. The analysis of EDX and SEM confirmed the formation of the extract precipitates on the metal surface, reducing the corrosion reaction. The biological test of the extract on Escherichia Coli culture shows that there no effect on the biological activity of Escherichia Coli and can be applied safely without any harmful effect on sanitation plants.
\end{abstract}

Keywords: Ocimum Basilicum, EDX -SEM, Sanitation plants, Escherichia coli.

\section{INTRODUCTION}

Metallic corrosion is attracting the attention of researches. Researchers all over the world are searching for some methods to avoid corrosion damage. Using extracts is an effective method to reduce corrosion rate [1]. Organic compounds are effective extracts of aqueous corrosion of many metals and alloys. The influence of organic compounds containing nitrogen, oxygen and sulphur atoms on the corrosion of the steel in acidic solutions has been investigated by several authors [2-7]. Such compounds can adsorb on the metal surface, blocking the active centers on the surface and thus reduces the corrosion rate. Extracts function by adsorption of ions or molecules onto metal surface. Sastri [8] in his review has given a vivid account of organic corrosion extracts including the classification and mechanism of action. He has attributed the corrosion inhibition potential to the donation of lone pair of electron to metal atoms. Most of investigated compounds are

\footnotetext{
${ }^{\star}$ Corresponding author: Abd El-Aziz S. Fouda

E-mail: asfouda@mans.edu.eg

Paper received: 18. 07. 2016.

Paper accepted: 22. 08. 2016.

Paper is available on the website: www.idk.org.rs/journal
}

toxic and cause severe environmental hazards. The use of natural products of plant origin as corrosion extracts for some metals and alloys have been reported by several authors [9-23]. The activity of corrosion inhibition of plant extracts could be due to the presence of heterocyclic constituents such as, alkaloids, flavonoids, tannins, cellulose and polycyclic compounds.

Ocimum Basilicum is particularly interesting because it is non-expensive, available, ecologically friendly acceptable and possess no threat to the environment.

The present work is undertaken: a) To evaluate the inhibition efficiency $(P)$ of an aqueous extract of Ocimum Basilicum in controlling the corrosion of CS in $3.5 \% \mathrm{NaCl}$ and $\mathrm{Na}_{2} \mathrm{~S}$ b) To investigate the influence of immersion period on the $P$ of the system c) To analyze the protective film formed on the CS by SEM and EDX and d) Studding the biological effect of Ocimum Basilicum on Escherichia coli activity.

\section{EXPERIMENTAL}

\subsection{Material composition of the sample}

The material used is CS which provided from Talkha sanitation plant, Egypt. The chemical 
composition (wt \%): $0.210 \mathrm{C}, 0.004 \mathrm{Si}, 0.360 \mathrm{Mn}$, $0.250 \mathrm{P}$ and the remainder is iron.

\subsection{Preparation of the extract (extract)}

An aqueous extract of Ocimum Basilicum plant was prepared by grinding a suitable amount of the plant leaves into a fine powder to give $500 \mathrm{~g}$ of powdered materials, a known quantity of the material was soxholated using doubled distilled water. Finally the extract was lyophilized, weighed and preserved at $4^{\circ} \mathrm{C}$ and used as and when required. The extract was used as corrosion extract in the present study.

\subsection{Preparation of bacterial agriculture media}

Suspend $50 \mathrm{~g}$ of the medium in 1 litter of distilled water and dissolve it by heating. Sterilize in autoclave at $121^{\circ} \mathrm{C}$ for $15 \mathrm{~min}$. Cool to $45-50^{\circ} \mathrm{C}$, mix well and dispense into plates. Allow the plates to solidify. The prepared medium should be at 8$15^{\circ} \mathrm{C}$. The color is violet-red.

\subsection{Solutions}

The aggressive solutions of $3.5 \% \mathrm{NaCl}$ and 16 ppm $\mathrm{Na}_{2} \mathrm{~S}$ was prepared by dissolving the required amount of salts in bi-distilled water. All chemicals were analytical-grade reagents. The experiments were carried out under non-stirred and naturally aerated conditions. The addition of the extract did not change the $\mathrm{pH}$ of the aggressive media.

\subsection{Weight-loss method}

A seven samples of CS of $2 \times 2 \times 0.1 \mathrm{~cm}$ as a dimension were polished using emery paper with different grits, followed by washing in ethanol and bi-distilled water, then immersed (complete immersion) in $100 \mathrm{ml}$ of the corrosive medium in a beaker containing various concentrations of the extract for about $180 \mathrm{~min}$. The weights of the specimens before and after immersion were determined using a Digital Balance (Model Denver Instrument).

\subsection{Potentiodynamic polarization method}

A three electrode cell assembly was used. The working electrode was carbon steel. A saturated calomel electrode (SCE) was the reference electrode. Platinum foil $\left(1 \mathrm{~cm}^{2}\right)$ was the counter electrode. From polarization study, corrosion parameters such as $\left(\mathrm{E}_{\text {corr }}\right)$, corrosion current $\left(\mathrm{i}_{\text {corr }}\right)$, Tafel slopes anodic $=\beta_{\mathrm{a}}$ and cathodic $=\beta_{\mathrm{c}}$ were calculated and polarization study was done. The scan rate was 1 $\mathrm{mVs}^{-1}$.

\subsection{Electrochemical impedance spectroscopy (EIS) method}

Impedance measurements were carried out using AC signals of amplitude $5 \mathrm{mV}$ peak to peak at the open-circuit potential in the frequency range
$100 \mathrm{kHz}$ and $0.2 \mathrm{~Hz}$. The real part $\left(Z_{\text {real }}\right)$ and imaginary part $\left(Z_{\text {imag }}\right)$ of the cell impedance were measured in ohms at various frequencies. Values of charge transfer resistance $\left(R_{c t}\right)$ and double layer capacitance $\left(\mathrm{C}_{\mathrm{dl}}\right)$ were calculated.

\subsection{Electrochemical frequency modulation (EFM) method}

Electrochemical frequency modulation was carried out using two frequencies 2 and $5 \mathrm{~Hz}$. The base frequency was $0.1 \mathrm{~Hz}$, so the waveform repeats after 1s. The Intermodulation spectra contain current responses assigned for harmonical and intermodulation current peaks. The larger peaks were used to calculate the corrosion current density ( $\left.i_{\text {corr }}\right)$, the Tafel slopes $\left(\beta_{\mathrm{c}}\right.$ and $\left.\beta_{\mathrm{a}}\right)$ and the causality factors CF-2\&CF-3 [24].

All electrochemical experiments were carried out using Potentiostat/Galvanostat/Zra analyzer (Gamry PCl300/4). A personal computer with DC105 software for polarization, EIS300 software for impedance, EFM140 software for electrochemical frequency modulation and Echem Analyst 5.21 was used for data fitting and calculating.

\subsection{Surface examination study}

The scanning electron microscopy (SEM) model JSM-6390AL was used to examine the specimen surface before and after immersion in corrosive media for 1 day. Meanwhile, the energy dispersive spectrometer (EDX) was used to analyze the elements in the specimen.

\section{RESULTS AND DISCUSSION}

\subsection{Weight loss measurements}

Weight loss of $\mathrm{CS}$ in $3.5 \% \mathrm{NaCl}$ and $16 \mathrm{ppm}$ $\mathrm{Na}_{2} \mathrm{~S}$ in the presence of different concentration of Ocimum Basilicum extract is measured and plotted in Figs. $2 a$ to $2 \mathrm{~d}$. From these figures, the weight loss was found to decrease in the presence of the studied extract. As the result the surface coverage $(\theta)$ and \% P of the extract will increase more clearly, which is listed in Table1. This surface coverage $(\theta)$ and $\% p$ were calculated using the following equation:

$$
\% P=\theta \times 100=\frac{W o-W i}{W o} \times 100
$$

where $W_{0}$ and $W_{i}$ are the weight loss in absence and presence of extract, respectively. The optimum value of inhibition was obtained at the concentration of $300 \mathrm{ppm}$ about $90.2 \%$ inhibition. This indicates that the adsorption process between the adsorbate (extract) and the CS surface was efficiently achieved and led to the formation of a metal-extract interaction [25]. 
Table 1- Effect of Ocimum Basilicum extract concentrations on weight loss $\left(\mathrm{mg} \mathrm{cm}^{-2}\right)$ and inhibition efficiency $(\% \mathrm{P})$ of $\mathrm{CS}$ in $3.5 \% \mathrm{NaCl}+16 \mathrm{ppm} \mathrm{Na} \mathrm{N}_{2} \mathrm{~S}$ at different temperatures

\begin{tabular}{|c|c|c|c|c|c|c|c|c|}
\hline \multirow{2}{*}{ Conc. ppm } & \multicolumn{2}{|c|}{$25^{\circ} \mathrm{C}$} & \multicolumn{2}{c|}{$30^{\circ} \mathrm{C}$} & \multicolumn{2}{c|}{$35^{\circ} \mathrm{C}$} & \multicolumn{2}{c|}{$40^{\circ} \mathrm{C}$} \\
\cline { 2 - 9 } & $\begin{array}{c}\text { Weight } \\
\text { loss mg } \\
\mathrm{cm}^{-2}\end{array}$ & $\% \mathrm{P}$ & $\begin{array}{c}\text { Weight loss } \\
\mathrm{mg} \mathrm{cm}\end{array}$ & $\% \mathrm{P}$ & $\begin{array}{c}\text { Weight loss } \\
\mathrm{mg} \mathrm{cm}^{-2}\end{array}$ & $\% \mathrm{P}$ & $\begin{array}{c}\text { Weight loss } \\
\mathrm{mg} \mathrm{cm}^{-2}\end{array}$ & $\% \mathrm{P}$ \\
\hline Blank & 0.70710 & ------ & 0.73230 & ------ & 0.77020 & ------- & 0.83333 & ------- \\
\hline 50 & 0.33928 & 52.0 & 0.39457 & 46.1 & 0.50612 & 34.3 & 0.58053 & 30.3 \\
\hline 100 & 0.28349 & 59.9 & 0.32797 & 55.2 & 0.39687 & 48.5 & 0.47258 & 43.3 \\
\hline 150 & 0.19097 & 73.0 & 0.23896 & 67.4 & 0.280576 & 63.6 & 0.33877 & 59.3 \\
\hline 200 & 0.13425 & 81.0 & 0.17564 & 76.0 & 0.22723 & 70.5 & 0.27897 & 66.5 \\
\hline 250 & 0.08580 & 87.9 & 0.12389 & 83.1 & 0.17563 & 77.2 & 0.22723 & 72.7 \\
\hline 300 & 0.06914 & 90.2 & 0.09390 & 87.2 & 0.11864 & 84.6 & 0.16798 & 79.8 \\
\hline
\end{tabular}
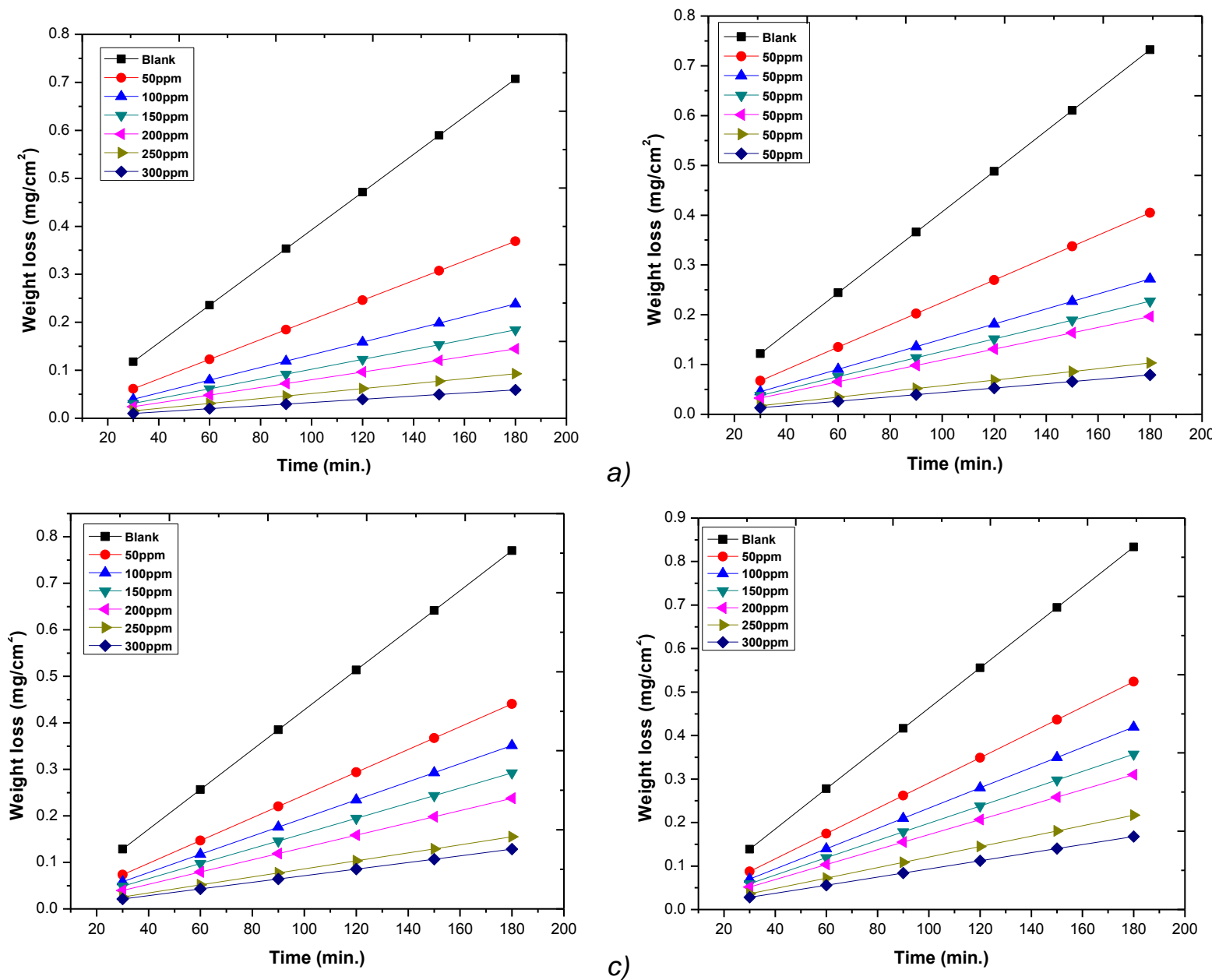

b)

Figure 2a-2d - Weight loss-time curves for the corrosion of CS in sulfide polluted salt water in absence and presence of Ocimum Basilicum extract at temperature $25^{\circ} \mathrm{C}-40^{\circ} \mathrm{C}$

\subsection{Effect of Temperature}

The effect of temperature on the corrosion rate of $\mathrm{CS}$ in $3.5 \% \mathrm{NaCl}$ and $16 \mathrm{ppm} \mathrm{Na}_{2} \mathrm{~S}$ in absence and presence of different concentration of Ocimum Basilicum extract was studied at different temperatures $\left(25-40^{\circ} \mathrm{C}\right)$ by weight loss method. The data of Table 1 and Fig. 3 show that (\%P) decreases as the temperature increases due to the desorption of extract molecules from the CS surface, and hence low surface coverage was obtained. Also, (\%P) increases with increasing extract concentration. The corrosion reactions are usually regarded as Arrhenius processes and the rate $(k)$ can be expressed by the relation in Eq. (2):

$$
k=A e^{\left(-E^{\star} a / R T\right)}
$$


where $k$ is the corrosion rate, $E_{a}^{*}$ is the apparent activation energy, $R$ is the universal gas constant, $T$ is the absolute temperature, and $A$ is the frequency factor. Fig.4 is Arrhenius plot (log $k$ against the reciprocal of temperature $(1 / T))$ for CS in $3.5 \% \mathrm{NaCl}$ and $16 \mathrm{ppm} \mathrm{Na} \mathrm{Na}_{2} \mathrm{~S}$ in the absence and presence of different concentrations of Ocimum Basilicum extract. Straight lines of high correlation coefficients were obtained. The values of activation energy, $E_{a}^{*}$ were $8.5,50.0 \mathrm{k} \mathrm{J} \mathrm{mol}^{-1}$ for the blank and in the presence of the extract, respectively. Also, since the activation energy, $E_{a}{ }^{*}$ is more than $40 \mathrm{~kJ} \mathrm{~mol}^{-1}$, the process is diffusion controlled [26]. The increase of $E_{a}^{*}$ in the presence of the extract indicates the physical adsorption or weak chemical bonding between the extract molecules and CS surface [27]. Enthalpy and entropy of activation $\left(\Delta \mathrm{H}^{*}, \Delta \mathrm{S}^{*}\right)$ are calculated from transition sate theory using the following equation [28].

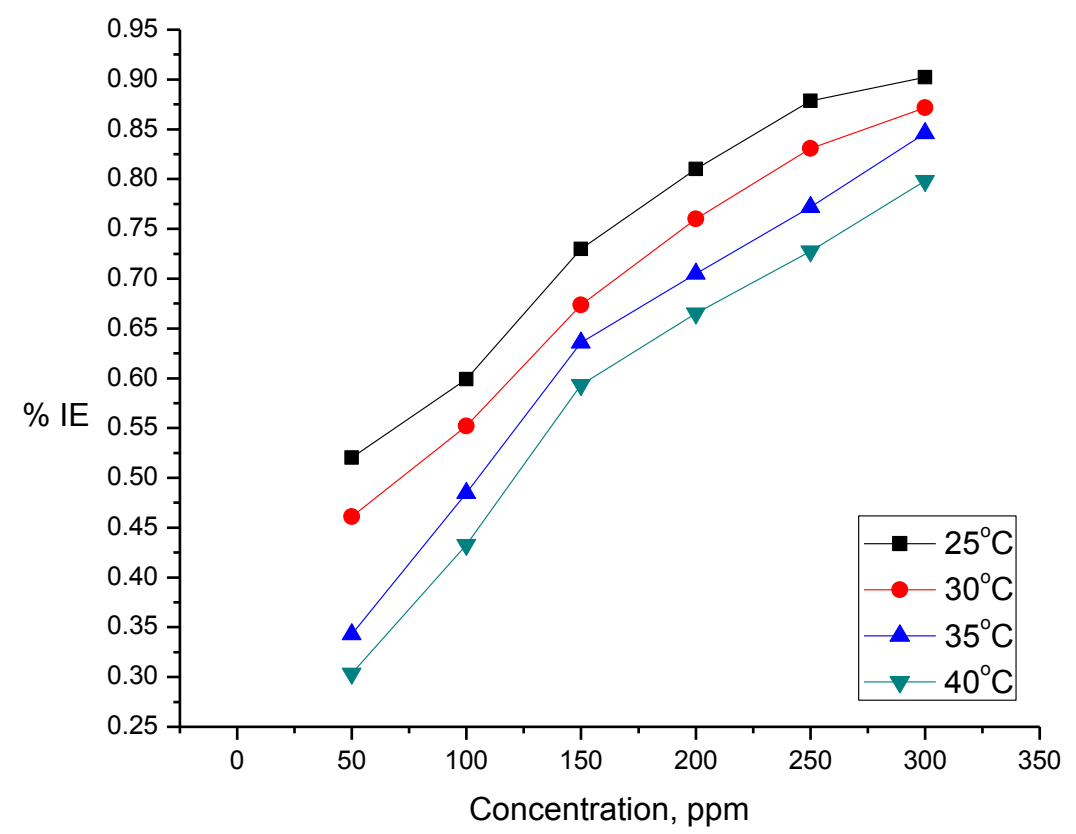

Figure 3 - The effect of extract concentration and temperature on the inhibition efficiency of Ocimum Basilicum extract.

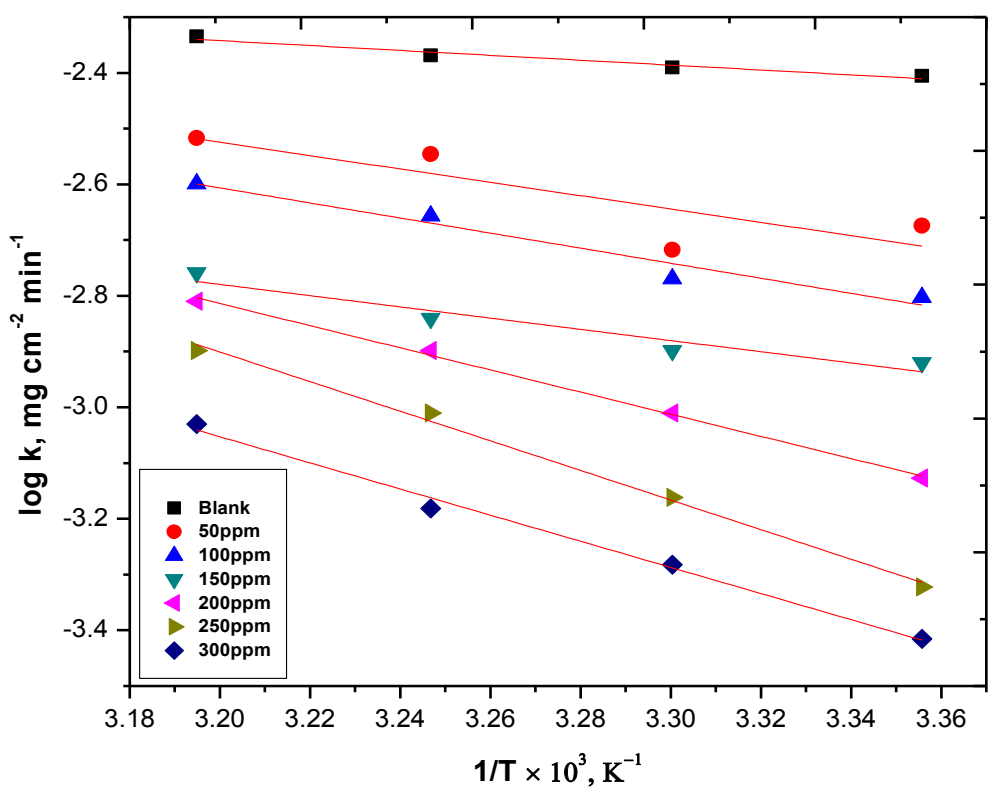

Figure 4 - Arrhenius plots for the corrosion rate of CS in sulfide polluted salt water in absence and presence of Ocimum Basilicum extract at different temperatures 
An alternative formulation of Arrhenius eq.:

$$
k=R T / N h \exp \left(\Delta S^{*} / R \exp \left(-\Delta H^{*} / R T\right)\right.
$$

where $\mathrm{h}$ is the Planck's constant and $\mathrm{N}$ is the Avogadro's number. Fig. 5 shows a plot of log k/T as a function of $1 / T$ for carbon steel. Straight lines were obtained with a slope of $-\Delta \mathrm{H}^{*} / \mathrm{R}$ and an intercept of In $R / N h+\Delta S^{*} / R$ from which the values of $\Delta \mathrm{H}^{*}$ and $\Delta \mathrm{S}^{*}$ were calculated for the blank and the extract. The values of the activation enthalpy, $\Delta \mathrm{H}^{*}$ were 18.0 and $49.4 \mathrm{~kJ} \mathrm{~mol}^{-1}$ and the values of the activation entropy, $\Delta \mathrm{S}^{\star}$ were $-147.9,-272.5 \mathrm{~J}$ $\mathrm{mol}^{-1} \mathrm{~K}^{-1}$ for the blank and the extract, respectively. The entropy of activation in absence and presence of extract is large and negative. This implies that the activated complex in the rate determining step represents an association rather than a dissociation step, meaning that a decrease in disordering takes place on going from reactants to the activated complex $[29,30]$. The positive sign of $\Delta \mathrm{H}^{*}$ indicates that the corrosion process is endothermic one.

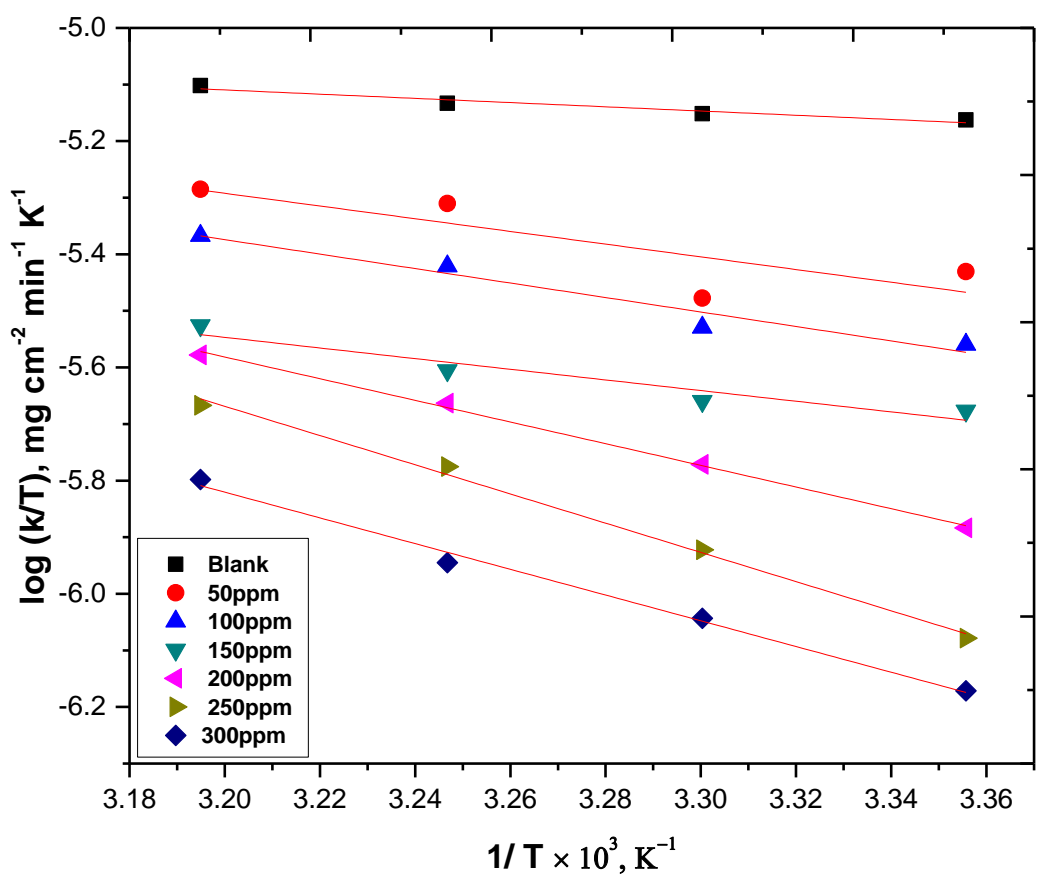

Figure 5 - Log $(k / T)$ versus 1/T for CS in sulfide polluted salt water in absence and presence of Ocimum Basilicum extract at different temperatures

\subsection{2- Adsorption isotherms}

Adsorption isotherm is importance to explain the mechanism of corrosion extract of organo electrochemical reactions. Process of adsorption occur when a liquid or gas accumulates on the surface of a solid or liquid, forming a molecular or atomic film. Assuming that the studied extract affect the rate of the corrosion process mainly through the variation of the degree of surface coverage $(\theta)$. Consequently, the inhibition efficiency is a function of the electrode surface covered by the extract molecules, i.e. $\theta=10^{2} \times$ $\% \mathrm{P}$. Attempts were made to fit the relationship between $\theta$ and the bulk concentration of the extract used at a certain given temperature in order to give an insight into the adsorption process. Several adsorption isotherms are commonly tried to characterize the extract performance and the best fit was obtained using Langmuir isotherm, which assumes that the solid surface contains a fixed number of adsorption sites and each site holds one adsorbed species [31], in good agreement with the following Eq.:

$$
C / \theta=I / K_{a d s}+C
$$

where $K_{a d s}$ is the equilibrium constant of the adsorption process. Variation of $(\mathrm{C} / \theta)$ with extract concentration (C) presented in Fig. 6 suggests that there is no attraction or repulsion forces between the adsorbed molecules, since a linear relationship is obtained with a slope equal to unity and intercept equal to $\left(1 / \mathrm{K}_{\mathrm{ads}}\right), \mathrm{K}_{\mathrm{ads}}$ being related to the standard free energy of adsorption $\left(\Delta \mathrm{G}^{\circ}{ }_{\text {ads }}\right)$ by the relation:

$$
K_{a d s}=(1 / 55.5) \exp \left(-\Delta G_{a d s}{ }^{0} / R T\right)
$$

where the constant 55.5 is the molar concentration of water in solution and $R$ is the universal gas constant. By applying Eq. (6), different values of $\Delta G^{\circ}{ }_{\text {ads }}$ of the extract as a function of temperature in the domain 298-313 K were obtained and listed in Table1. Fig.7 shows 
that the dependence of $\Delta G^{\circ}$ ads on the absolute temperature ( $T$ ) gives linear plot with a slope equal to the entropy of adsorption $\left(\Delta S^{\circ}{ }_{\text {ads }}\right)$ and intercepts equal to the enthalpy of adsorption $\left(\Delta \mathrm{H}^{0}\right.$ ads $)$, according to the following Eq.:

$$
\Delta G^{o}{ }_{\text {ads }}=\Delta H^{\circ} \text { ads }-T \Delta S^{o} \text { ads }
$$

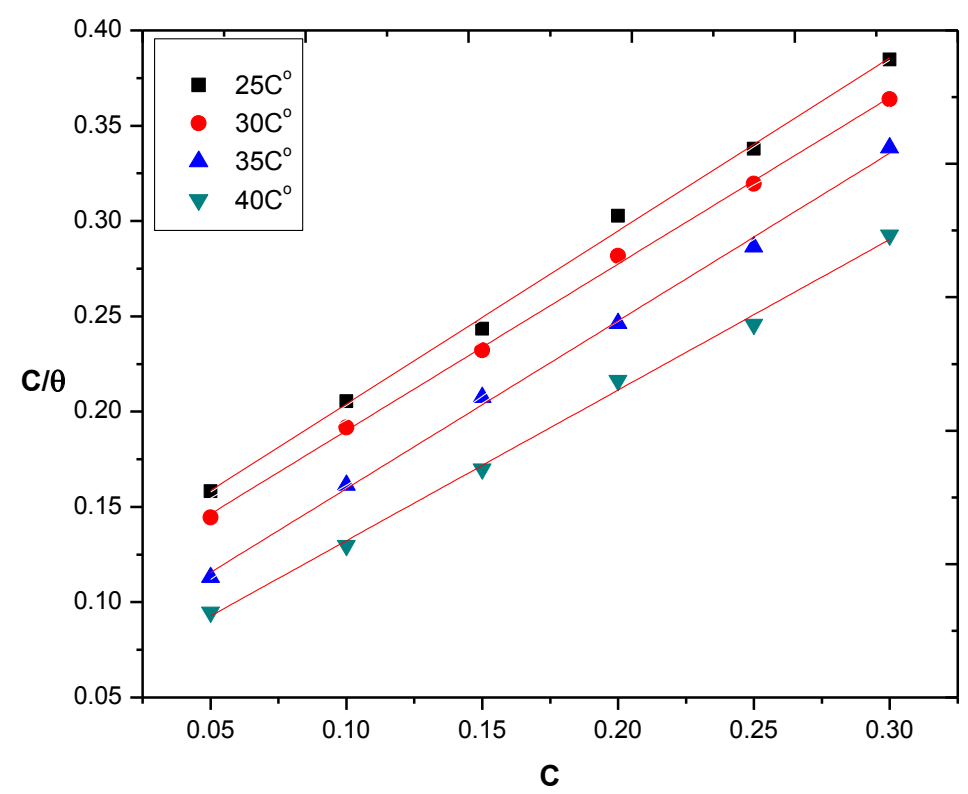

Figure 6 - Langmuir adsorption isotherm for Ocimum Basilicum extract at different temperature for the CS in sulfide polluted salt water

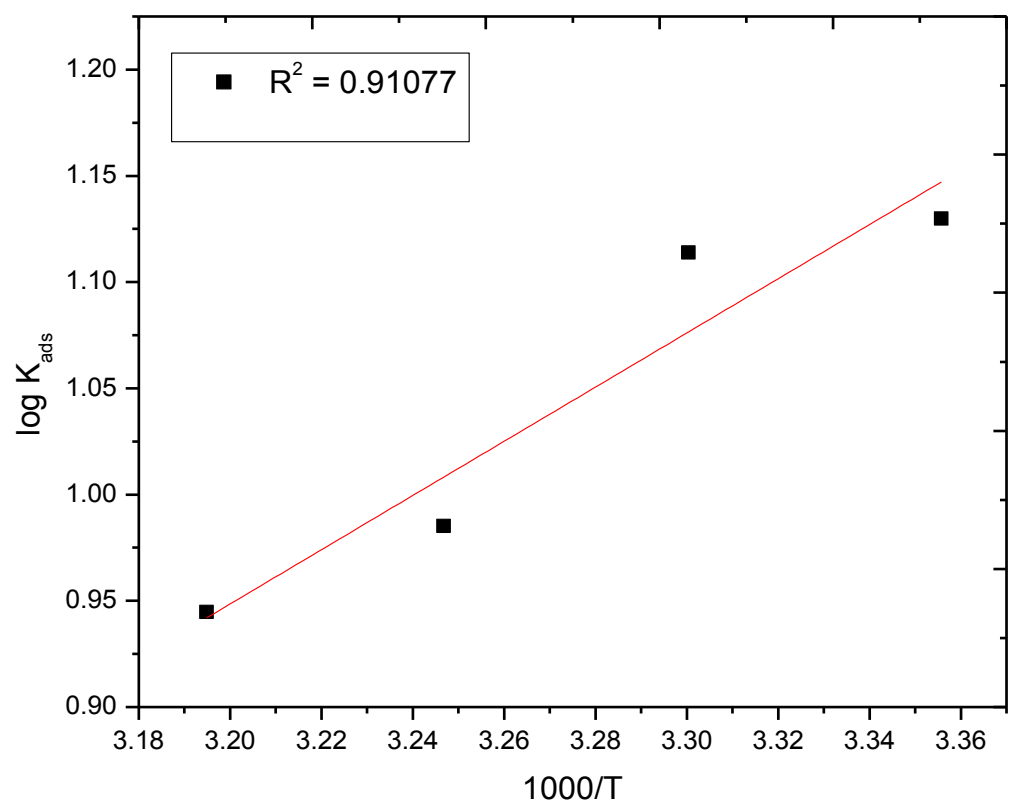

Figure 7 - Log $K_{\text {ads }}$ vs 1000/T for the corrosion of the CS in presence of Ocimum Basilicum extract.

The various thermodynamic functions for the adsorption process $\left(K_{a d s}^{\circ}, \Delta G^{\circ}{ }_{a d s}, \Delta H^{\circ}{ }_{\text {ads }}\right.$, and $\Delta S^{\circ}{ }_{a d s}$ ) are given in Table 2 . It is generally obvious that $\Delta G^{\circ}$ ads has increasingly negative value, as the $\% \mathrm{P}$ increases, which indicates that the tested extract is adsorbed spontaneously on CS surface forming a relatively stable adsorbed layer. The values of $\Delta G^{\circ}$ ads is ranged from 15.8 to $17.4 \mathrm{~kJ} \mathrm{~mol}^{-1}$, indicating that the adsorption mechanism of the
Ocimum Basilicum on CS surface involves physical adsorption. The $K_{\text {ads }}^{\circ}$ follows the same trend in the sense. The negative sign of $\Delta H^{\circ}$ ads reveals that adsorption of the extract on CS surface is an exo thermic process. Such behavior can be explained on the basis that temperature rise causes desorption of some adsorbed extract molecules of the metal surface and consequently leads to formation of surface organic layer having lower protection. 
Table 2 - Adsorption parameters for CS in absence and presence of various concentration of Ocimum Basilicum extract

\begin{tabular}{|c|c|c|c|c|}
\hline $\begin{array}{c}\text { Temp. } \\
\mathrm{K}\end{array}$ & -Log $\mathrm{K}_{\mathrm{ads}}$ & $\begin{array}{c}-\Delta \mathrm{G}^{\circ}{ }_{\mathrm{ads}} \\
\mathrm{kJ} \mathrm{mol}^{-1}\end{array}$ & $\begin{array}{c}-\Delta \mathrm{H}^{\circ} \\
\mathrm{kJ} \mathrm{mol}^{-1}\end{array}$ & $\begin{array}{c}-\Delta \mathrm{S}^{\circ} \\
\mathrm{kJ} \mathrm{mol}^{-1}\end{array}$ \\
\hline 298 & 1.19350 & 15.8 & & 0.02943 \\
\hline 303 & 1.12188 & 16.1 & \multirow{2}{*}{24.7} & 0.02804 \\
\hline 308 & 0.97189 & 17.0 & & 0.02598 \\
\hline 313 & 0.94840 & 17.4 & & 0.02339 \\
\hline
\end{tabular}

\subsection{Polarization measurements}

Polarization measurement is the technique which gives the mechanism of the inhibition. The changes observed in the polarization curves after addition of the extract are usually used as criteria to classify extracts as cathodic, anodic or mixed. Tafel polarization curve for $\mathrm{CS}$ in $3.5 \% \mathrm{NaCl}$ and $16 \mathrm{ppm} \quad \mathrm{Na}_{2} \mathrm{~S}$ solution containing various concentrations of Ocimum Basilicum at $25^{\circ} \mathrm{C}$ was recorded. Fig. 8 shows a typical example for Ocimum Basilicum.

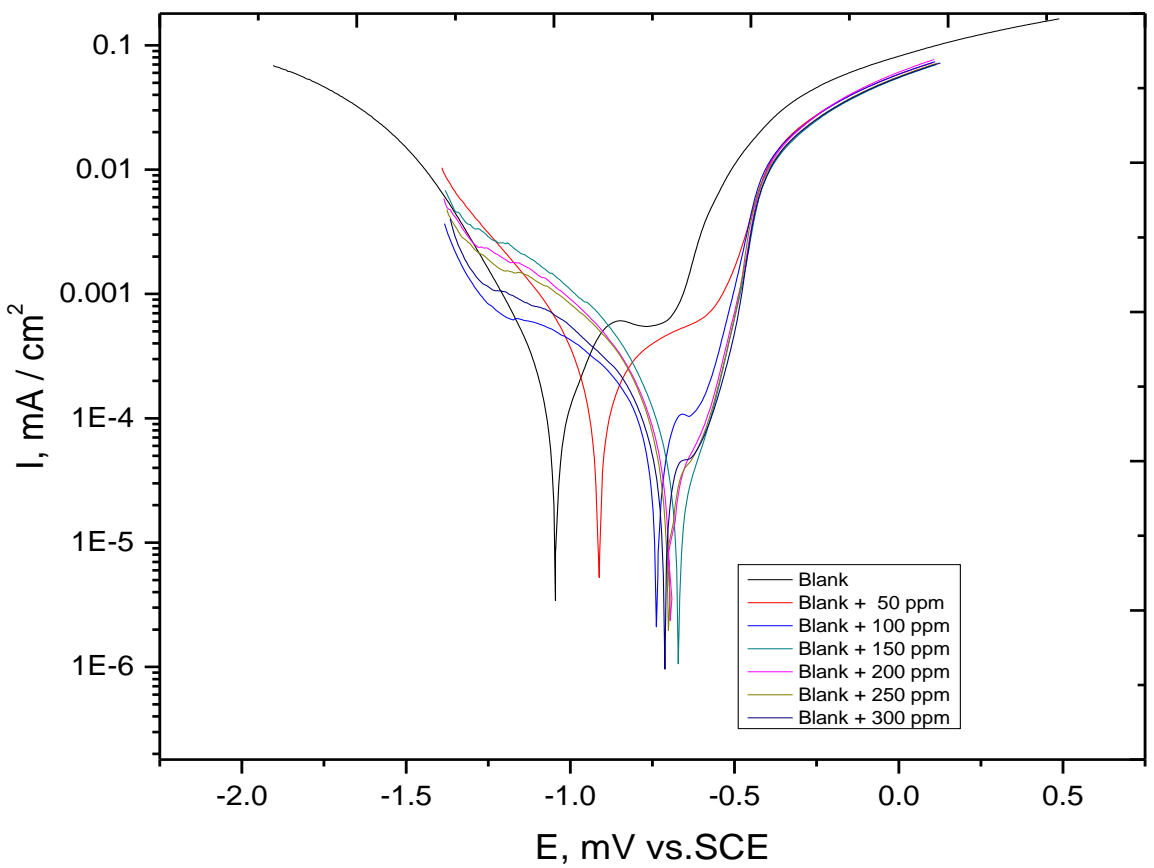

Figure 8 - Potentiodynamic polarization curves for the corrosion of CS in sulfide polluted salt water in the absence and presence of different concentrations of Ocimum Basilicum extract at $25^{\circ} \mathrm{C}$

The values of inhibition efficiency percentage $\% \mathrm{P}$ and the degree of surface coverage $\theta$ at each concentration was calculated using the equation $[32,33]:$

$$
\% P=\Theta \times 100=\left[1-\left(i_{\text {corr (inh) }} / i_{\text {corr }}\right)\right] \times 100
$$

where $\mathrm{i}_{\text {corr }}$ and $\mathrm{i}_{\text {corr(inh) }}$ are the corrosion current densities of uninhibited and inhibited solution, respectively. From Table 3 , the increase in the extract concentration from 50 to $300 \mathrm{ppm}$ was accompanied by a decrease in $\mathrm{i}_{\text {corr }}$ and an increase in \%P from 45.8 to $88.5 \%$ for Ocimum Basilicum. These results lead to the conclusion that the investigated extract is fairly efficient extract towards CS dissolution in the corrosive medium. The positive shift in $E_{\text {corr }}$ indicates an increase in the effectiveness of the cathodic process, which in turn decreases the rate of the anodic one $[34,35]$. Also, the data of Table 3 , the anodic Tafel slope $\left(\beta_{a}\right)$ is higher than $\beta_{c}$ and slightly decreases on increasing the concentration of the extract. This indicates that addition of the extract dose not modify the mechanism of the corrosion of CS in the corrosive medium. The fact that $\beta_{\mathrm{a}}$ value is higher than $\beta_{\mathrm{c}}$ can be attributed to a surface kinetic process rather than a diffusion-controlled one [36], indicating that the inhibition mode of Ocimum Basilicum is by simple blockage of the surface via adsorption. Increasing extract concentration increase the degree of surface coverage by the adsorbed inhibiting species by the donor atoms of the oxygen, electron clouds of the benzene rings, and also the bulky group of the extract, which hinder the diffusion of ions to or from the electrode surface [37]. This in turn leads to a decrease in the anodic dissolution current density of carbon steel. 
Table 3 - The effect of concentration of Ocimum Basilicum extract on the electrochemical parameters calculated by using potentiodynamic technique for corrosion of CS in sulfide polluted salt water at $25^{\circ} \mathrm{C}$

\begin{tabular}{|c|c|c|c|c|c|c|c|}
\hline Conc. ppm & $\begin{array}{c}-E_{\text {corr }}, \mathrm{mV} \\
\text { vs SCE }\end{array}$ & $\begin{array}{c}\mathrm{i}_{\text {corr, }} \\
\mu \mathrm{A} \mathrm{cm}\end{array}$ & $\begin{array}{c}-\beta_{c}, \\
\mathrm{mV} \mathrm{dec}^{-1}\end{array}$ & $\begin{array}{c}\beta_{\mathrm{a}}, \\
\mathrm{mV} \mathrm{dec}^{-1}\end{array}$ & $\begin{array}{c}\mathrm{C} . \mathrm{R} \\
\mathrm{mmy}^{-1}\end{array}$ & $\theta$ & $\% \mathrm{P}$ \\
\hline Blank & 1040 & 264 & 320 & 507 & 120 & ----- & ---- \\
\hline 50 & 913 & 143 & 244 & 349 & 65 & 0.458 & 45.8 \\
\hline 100 & 907 & 110 & 270 & 488 & 50 & 0.584 & 58.4 \\
\hline 150 & 713 & 85 & 246 & 369 & 39 & 0.676 & 67.6 \\
\hline 200 & 699 & 49 & 248 & 357 & 22 & 0.814 & 81.4 \\
\hline 250 & 670 & 36 & 246 & 363 & 16 & 0.865 & 86.5 \\
\hline 300 & 694 & 30 & 244 & 361 & 14 & 0.885 & 88.5 \\
\hline
\end{tabular}

\subsection{Electrochemical impedance spectroscopy}

(EIS) measurements

Impedance measurements provide information on both the resistive and capacitive behavior of the interface, evaluation on the performance of studied compounds as possible corrosion extract, and investigation of the corrosion inhibition processes. Corrosion behavior of $\mathrm{CS}$ in $3.5 \% \mathrm{NaCl}$ and 16 ppm $\mathrm{Na}_{2} \mathrm{~S}$ with and without Ocimum Basilicum extract was investigated by using electrochemical impedance spectroscopy (EIS) measurements. The charge-transfer resistance $\left(R_{t}\right)$ values are calculated from the difference in impedance at lower and higher frequencies, as suggested by Tsuru et al [38]. The double-layer capacitance $\left(C_{d 1}\right)$ and the frequency at which the imaginary component of the impedance is maximal $\left(-Z_{\max }\right)$ are found as represented in the following equation:

$$
C_{d l}=\frac{1}{2 \pi f_{\max } R_{t}}
$$

where $f_{\max }$ is maximum frequency at which the imaginary component of the impedance $\left(Z_{i m}\right)$ is maximum at $R_{t}$ is diameter of the loop. The inhibition efficiency got from the charge transfer resistance is calculated by:

$$
\% E_{E I S}=100 \times\left[1-\left(R_{t} / R_{t \text { inh }}\right)\right]
$$

$R_{t}$ and $R_{t \text { tinh }}$ are the charge-transfer resistance values without and with extract, respectively.

Table 4 - Electrochemical kinetic parameters obtained by EIS technique for the corrosion of CS using Ocimum Basilicum extract as extract in sulfide polluted salt water at $25^{\circ} \mathrm{C}$.

\begin{tabular}{|c|c|c|c|c|c|c|}
\hline $\begin{array}{c}\text { Conc., } \\
\mathrm{ppm}\end{array}$ & $\begin{array}{c}\mathrm{R}_{\mathrm{s}} \\
\Omega \mathrm{cm}^{2}\end{array}$ & $\begin{array}{c}\mathrm{C}_{d l} \\
\mu \mathrm{Fcm}^{-2}\end{array}$ & $\mathrm{n}$ & $\begin{array}{c}\mathrm{R}_{\mathrm{ct}} \\
\Omega \mathrm{cm}^{2}\end{array}$ & $\theta$ & $\% \mathrm{P}$ \\
\hline Blank & 5.561 & 163.74 & 0.867 & 31.72 & ---- & $\cdots$ \\
\hline 50 & 4.021 & 93.00 & 0.883 & 105.43 & 0.438 & 43.8 \\
\hline 100 & 4.511 & 72.19 & 0.864 & 298.16 & 0.565 & 56.5 \\
\hline 150 & 4.984 & 57.70 & 0.892 & 393.46 & 0.654 & 65.4 \\
\hline 200 & 4.890 & 36.35 & 0.856 & 503.82 & 0.784 & 78.4 \\
\hline 250 & 4.128 & 26.08 & 0.877 & 587.28 & 0.853 & 85.3 \\
\hline 300 & 4.766 & 22.36 & 0.898 & 627.63 & 0.876 & 87.6 \\
\hline
\end{tabular}

Figure 9 showed the results of EIS experiments in the Nyquist representation. After analyzing the shape of the Nyquist plots, it is concluded that the curves approximated by a single capacitive semicircles, showing that the corrosion process was mainly charge transfer controlled [39]. The fact that impedance diagrams have an approximately semicircular appearance shows that the corrosion of CS is controlled by a charge transfer process.
The general shape of the curves is very similar for all samples, indicating that almost no change in the corrosion mechanism occurred due to the extract addition [40]. The diameter of Nyquist plots increases on increasing the extract concentration. These results suggested that the inhibition efficiency increases by increasing extract concentrations. It was observed from the obtained EIS data the charge transfer resistance $\left(R_{c t}\right)$ 
increases and double layer capacitance $\left(\mathrm{C}_{\mathrm{dl}}\right)$ decreases with the increasing of extract concentrations. The increase in $R_{c t}$ values, and consequently of inhibition efficiency, may be due to the gradual replacement of water molecules by the adsorption of the extract molecules on the metal surface to form an adherent film on the metal surface by the film decreases the double layer thickness. The results indicate good agreement between the values of corrosion efficiency as obtained from the impedance technique and polarization measurements. It was concluded that the corrosion rate depends on the chemical nature of the electrolyte rather than the applied technique [41]. The EIS data were simulated using equivalent electric circuits as shown in Fig. 10 where $R_{S}$ represents the solution or electrolyte resistance, $\mathrm{C}_{\mathrm{dl}}$ the double layer capacitance, $R_{c t}$ the charge transfer resistance.

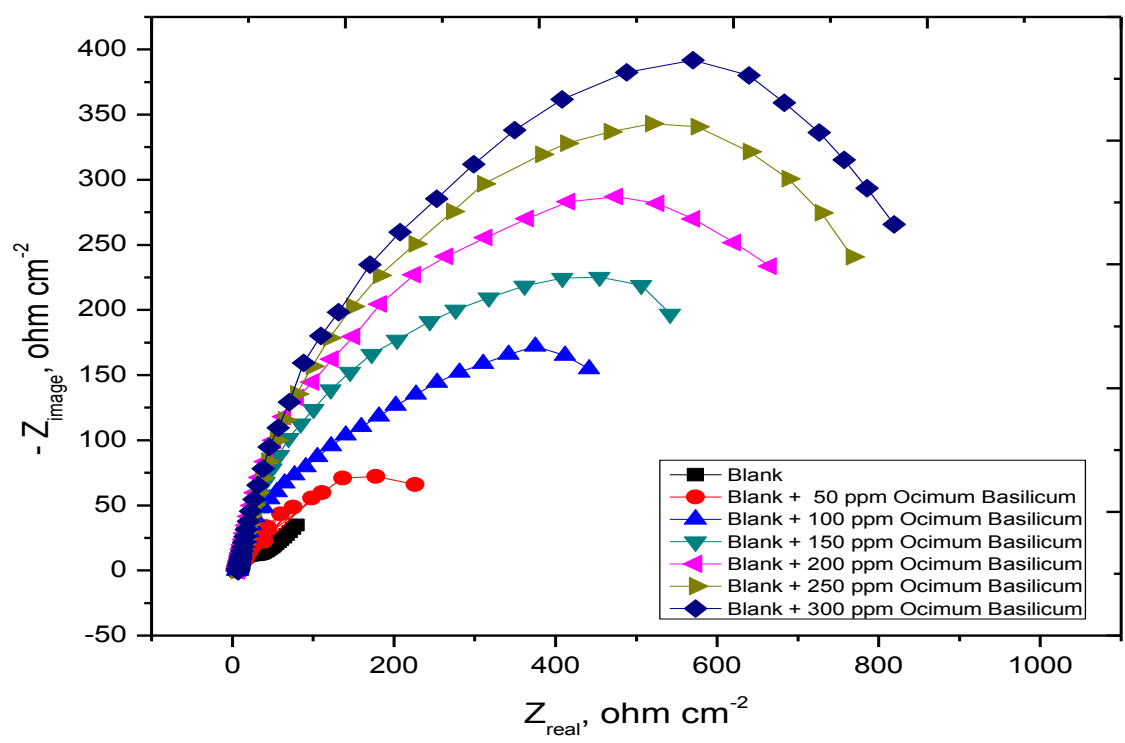

Figure 9 - Nyquist plots recorded for the CS in sulfide polluted salt water in the absence and presence of different concentrations of Ocimum Basilicum extract at $25^{\circ} \mathrm{C}$

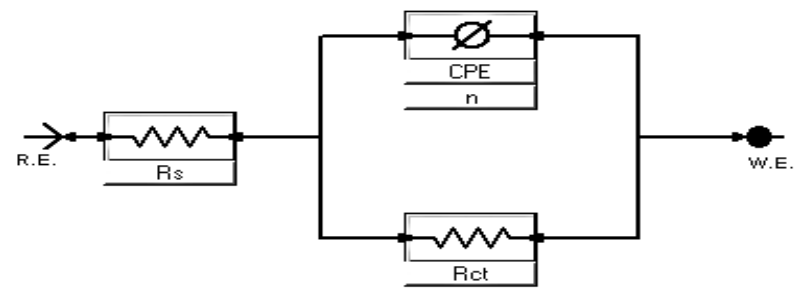

Figure 10 - Electrical equivalent circuit used to fit impedance data

\subsection{Electrochemical frequency modulation (EFM) measurements}

Intermodulation spectra obtained from EFM measurements are presented in Fig. $(11 a, b)$ as examples of $\mathrm{CS}$ in $3.5 \% \mathrm{NaCl}$ and $16 \mathrm{ppm} \mathrm{Na}_{2} \mathrm{~S}$ containing $300 \mathrm{ppm}$ of Ocimum Basilicum extract at $25^{\circ} \mathrm{C}$. Each spectrum is a current response as a function of frequency. The corrosion kinetic parameter of Ocimum Basilicum extract at different concentration in $3.5 \% \mathrm{NaCl}$ and $16 \mathrm{ppm} \mathrm{Na} \mathrm{Na}_{2} \mathrm{~S}$, are calculated and listed in Table 5 at $25^{\circ} \mathrm{C}$ giving the values of ( $i_{\text {corr }}, \beta_{c}, \beta_{a}, C F-2, C F-3$, and $\% \mathrm{P}$ ).

According to Table 5 , the increase in the Ocimum Basilicum concentration is followed by decreasing in corrosion current densities and increasing in inhibition efficiencies. The causality factors according to Table 5 are very close to theoretical values which according to EFM theory should guarantee the validity of Tafel slope and corrosion current densities. Values of causality factors in Table 5 indicate that the measured data are of good quality [42]. The standard values for CF-2 and CF-3 are 2.0 and 3.0, respectively. The obtained results showed good agreement of inhibition efficiency obtained from the weight loss, potentiodynamic polarization, EIS and EFM methods. 
Table 5 - Electrochemical Kinetic parameters obtained by EFM technique for CS in $3.5 \% \mathrm{NaCl}+16 \mathrm{ppm}$ $\mathrm{Na}_{2} \mathrm{~S}$ alone and with different concentrations of Ocimum Basilicum extract at $25^{\circ} \mathrm{C}$

\begin{tabular}{|c|c|c|c|c|c|c|c|c|}
\hline$\% \mathrm{P}$ & $\Theta$ & $\begin{array}{c}\mathrm{C} . \mathrm{R}, \\
\mathrm{mmy}\end{array}$ & $\mathrm{CF}-3$ & $\mathrm{CF}-2$ & $\begin{array}{c}\beta_{\mathrm{c}}, \\
\mathrm{mV} \mathrm{dec}^{-1}\end{array}$ & $\begin{array}{c}\beta_{\mathrm{a}}, \\
\mathrm{mV} \mathrm{dec}^{-1}\end{array}$ & $\begin{array}{c}\mathrm{i}_{\text {corr., }} \\
\mu \mathrm{A} \mathrm{cm}\end{array}$ & $\begin{array}{c}\text { Conc. } \\
\mathrm{ppm}\end{array}$ \\
\hline----- & ----- & 309.9 & 2.891 & 1.933 & 186 & 135 & 678.2 & blank \\
\hline 44.9 & 0.449 & 170.9 & 2.882 & 1.892 & 206 & 148 & 374.0 & 50 \\
\hline 58.2 & 0.582 & 129.5 & 2.993 & 1.954 & 214 & 114 & 283.5 & 100 \\
\hline 66.6 & 0.666 & 103.4 & 2.979 & 1.994 & 169 & 90 & 226.4 & 150 \\
\hline 80.6 & 0.806 & 60.2 & 2.987 & 1.987 & 181 & 113 & 131.7 & 200 \\
\hline 86.3 & 0.863 & 42.3 & 2.993 & 1.990 & 213 & 134 & 92.6 & 250 \\
\hline 87.9 & 0.879 & 37.6 & 2.988 & 1.995 & 196 & 115 & 82.2 & 300 \\
\hline
\end{tabular}
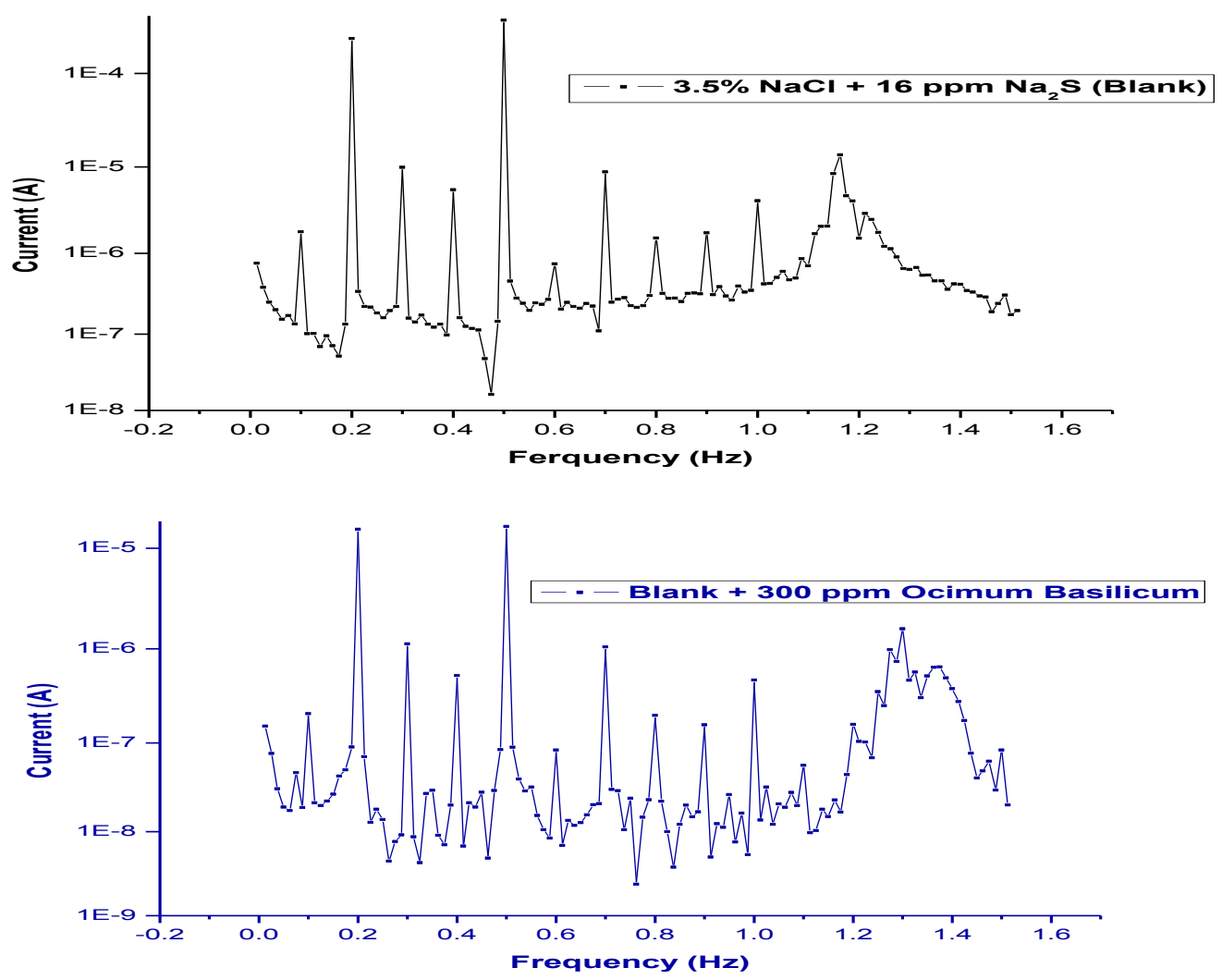

b)

Figure 11a-b - Intermodulation spectrum for CS in sulfide polluted salt water in absence and presence of $300 \mathrm{ppm}$ of Ocimum Basilicum extract at $25^{\circ} \mathrm{C}$

\subsection{Surface Characterization}

Figure $12 \mathrm{a}$ represents the image of CS surface. Figure 13a gives us the oxide film formed on the metal surface after immersion in the corrosive media for about 5 days making the surface be distorted by a porous layer of oxide film. Fig. 14a shows how the extract can absorbed and form a thin layer on the metal surface making a passivation from the corrosive media making the surface free from any damage and be smooth.

Figure $12 \mathrm{~b}$ is the SEM spectroscopy of the CS surface only without any addition. The characteristic peaks are related to the metal sample. Figure 13a representing the SEM peaks of the metal surface after immersion in $3.5 \% \mathrm{NaCl}$ and $16 \mathrm{ppm} \mathrm{Na}_{2} \mathrm{~S}$ for about 5 days, and the peaks is related to surface elements with the oxide film formed on it, that we found peaks of $\mathrm{Fe}, \mathrm{Mn}, \mathrm{Cl}$, $\mathrm{Na}, \mathrm{S}$, and Oxygen atoms. Figure $14 \mathrm{a}$ representing the peaks of the metal surface after immersion in $300 \mathrm{ppm}$ of Ocimum Basilicum with the corrosive medium for about 5 days. We found the peak of Fe element decreases and the peak of oxygen is raising, this indicates that the extract covers the metal surface and the $\mathrm{Fe}$ atoms become less than in Fig.13a, so the passivation occurred and prevent the formation of the oxide layer to be formed. So that Ocimum Basilicum extract is a good extract for $\mathrm{CS}$ at $300 \mathrm{ppm}$ concentration. 


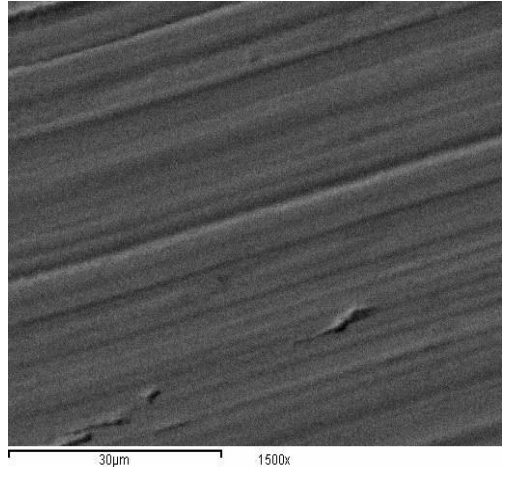

Figure $12 a-E D X$ of pure CS surface

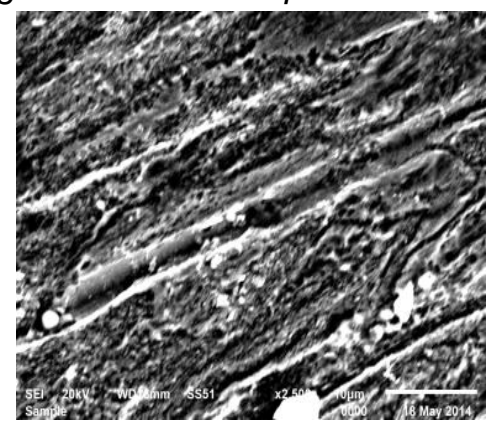

Figure 13a - EDX of CS surface after immersion in

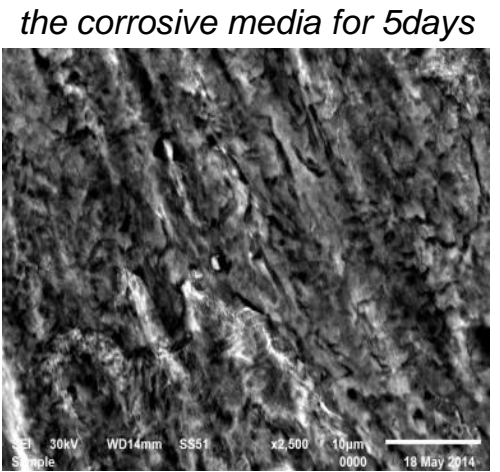

Figure $14 a$ - EDX of CS surface after immersion in the corrosive media and 300ppm Ocimum Basilicum extract for 5 days

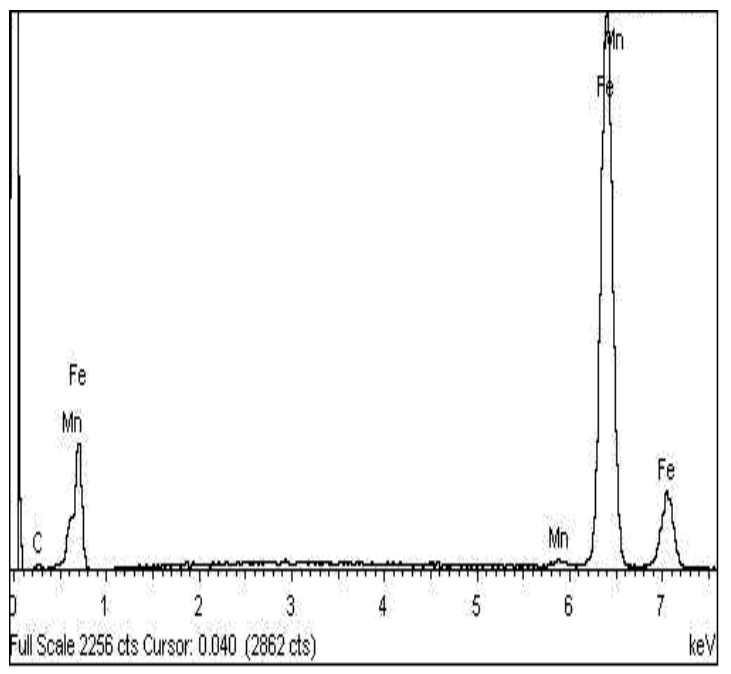

Figure $12 b$ - SEM of pure CS surface

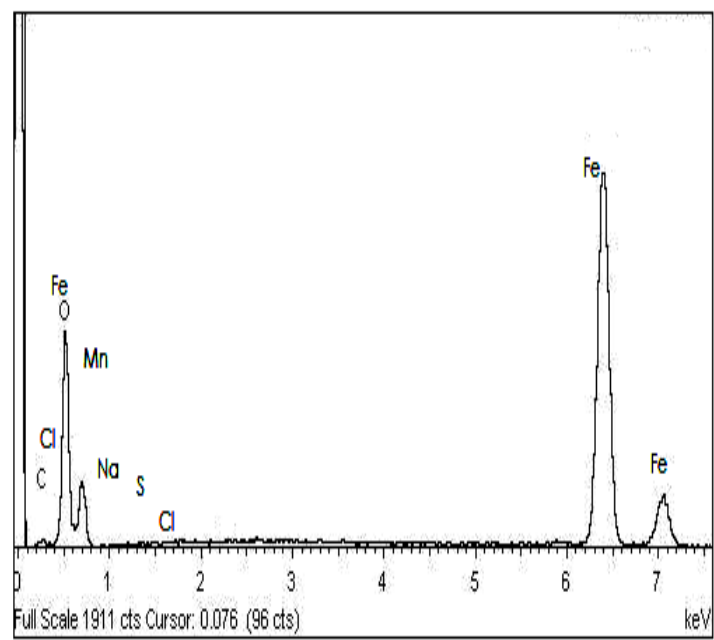

Figure $13 b$ - SEM of CS surface after immersion in the corrosive media for 5 days

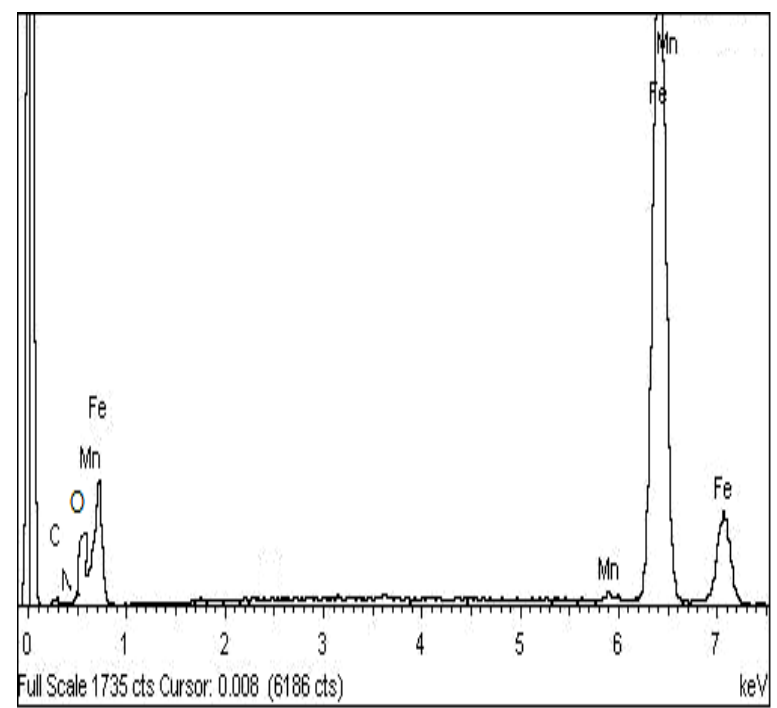

Figure $14 b$ - SEM of CS surface after immersion in the corrosive media and 300 ppm Ocimum Basilicum extract for 5 days

\subsection{Biological Effect of Ocimum Basilicum on} Escherichia Coli

A bacterial agriculture of Escherichia Coli is operated in absence and presence of Ocimum Basilicum extract. It was found that no effect on the activity of Escherichia Coli which presented in Table 6 and Fig. 15.

Table 6 - Results obtained from the plate counter for bacterial agriculture

\begin{tabular}{|c|c|c|c|}
\hline CFU mean) & CFU (R2) & CFU (R1) & Samples \\
\hline $92 \times 104$ & $95 \times 104$ & $89 \times 104$ & Control \\
\hline $90 \times 104$ & $93 \times 104$ & $86 \times 104$ & $\begin{array}{c}\text { Ocimum } \\
\text { Basilicum }\end{array}$ \\
\hline
\end{tabular}


The reason for this phenomenon is due to the Ocimum Basilicum structure, which has an oxygen donor atom, and it thought that it attached with the proteins and lipids of the bacterial tissues helping it in respiration process. So this extract has no toxicity on the bacterial activity, and can be applied safety on the sanitation plants without any problems in the treating operations.

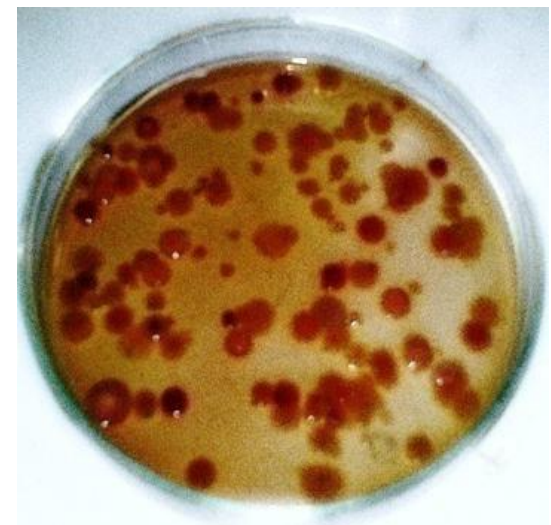

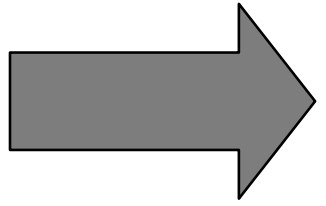

Blank

The bacterial agriculture in presence of 300 ppm of Ocimum Basilicum

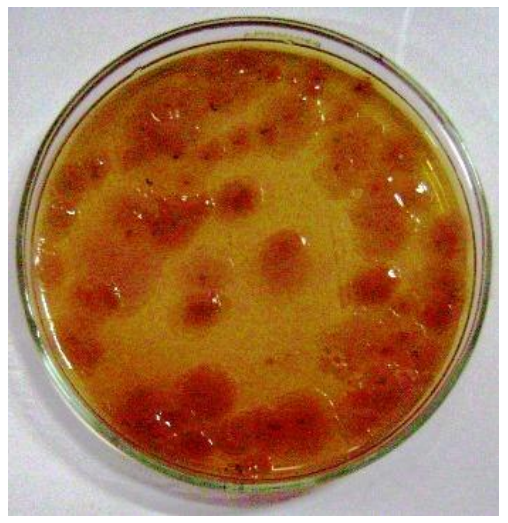

Figure 15 - The bacterial agriculture in absence and presence of Ocimum Basilicum extract

\subsection{Mechanism of corrosion inhibition}

The polar organic compounds exist in the extract are adsorbed on the CS surface, forming a charge transfer complex between their polar atoms and the CS surface. The size, shape and orientation of the molecules and the electronic charge on it determine the degree of adsorption and hence the effectiveness of the extract $[43,44]$. Ocimum Basilicum extract is most efficient extract because the presence of larger number of benzene rings in their molecules which contribute the electrons to the adsorption active centers and hence increases the electron density on the adsorption centers on the CS surface, leading to controlling the anodic metal dissolution and cathodic hydrogen evolution. The adsorption rate is usually rapid and hence the reactive centers on the metal surface are shielded from the aggressive environment.

\section{CONCLUSION}

According to the obtained results, the following conclusions can be drawn:

1. Ocimum Basilicum extract acts as corrosion inhibitor for CS in sulfide polluted salt water, giving efficiency reaches to $88.5 \%$ at $300 \mathrm{ppm}$ concentration.

2. The adsorption of Ocimum Basilicum on the CS follows Langmuir adsorption isotherm, it was proved to be an effective eco-friendly and low cost extract.

3. The negative free energy $\left(-\Delta G^{\circ}{ }_{\text {ads }}\right)$ of adsorption indicates strong and spontaneous adsorption of Ocimum Basilicum extract on the CS surface.

4. Values of Tafel constant $\left(\beta_{\mathrm{a}}\right.$ and $\beta_{\mathrm{c}}$ ) confirm that the extract is a mixed type but predominant cathodic effect.
5. The inhibition efficiency determined by different electrochemical methods is in reasonable good agreement.

6. This extract has no effect on the biological activity of Escherichia Coli, and can be applying safety on sanitation plants.

\section{REFERENCE}

[1] X.Li, L.Tang (2005) Kinetics of Corrosion inhibition of aluminum in acidic media by water-soluble natural polymeric pectates as anionic polyelectrolyte extracts, Mater. Chem. Phys., 90, 286-297.

[2] G. Br.Schmitt (1984) Using methyl urea as extract for the corrosion of carbon steel in $1 \mathrm{M} \mathrm{HCl}$ Medium, Corrosion, 49, 165-176.

[3] 3. A.S.Fouda, A.Hussein (2012) Role of Some Phenylthiourea Derivatives as Corrosion Extracts for $\mathrm{CS}$ in $\mathrm{HCl}$ Solution, J. of the Korean Chem. Soc., 65(2), 264-273.

[4] S.Rengamani, S.Muralidharan, M.Anbu Kulandainathan, S.V.K.lyer (2000) Effect of piperidones on hydrogen permeation and corrosion inhibition of mild steel in acidic solutions, Proc. Indian Acad. Sci., 112(2), 172-136.

[5] B.Hammouti (1996) Electrochemical behavior of parachloranil in carbon paste electrode in concentrated phosphoric acid media, J. Electrochem. Soc. India, 45(3), 164-166.

[6] N.Lahhit, A.Bouyanzer, J.M.Desjobert (2010) Essential oil as green corrosion Extract of CS in $\mathrm{HCl}$ Solution, Port Electrochim. Acta, 29(2), 127-138.

[7] A.A.El Maghraby, T.Y.Soror (2010) Quaternary ammonium salt as effective corrosion extract for CS dissolution in sulphuric acid media, Advanc. Appl. Sci., 1(2), 143-155.

[8] V.S.Sastri (1998) Corrosion Extracts-Principles and Applications, Wiley: Chichester, England.Res., 1(2), 143-155. 
[9] 9. U.J.Ekpe, E.E.Ebenso, U.J.Ibok (1994) Extracty action of Azadirachta indica leaves extract on the corrosion of mild steel in $\mathrm{H}_{2} \mathrm{SO}_{4}$, J. West Afr. Sci. Assoc, 37,13-30.

[10] E.E.Ebenso, U.J.Ekpe (1996) Kinetic study of corrosion and corrosion inhibition of mild steel in $\mathrm{H}_{2} \mathrm{SO}_{4}$ using Carica papaya leaves extract, West Afr. J. Biol. Appl. Chem, 41, 21-27.

[11] G.O.Avwiri, F.O.Igho (2001) Inhibitive action of Vernonia amygdalina on the corrosion of aluminium alloys in acidic media, Mater Lett 57, 3705-3711.

[12] E.E.Ebenso, U.J.lbok, U.J.Ekpe (2004) Corrosion inhibition studies of some plant extracts on aluminium in acidic medium, Trans SAEST, 39, 117-123.

[13] A.Y.El-Etre, Z. El-Tantawy (2006) Inhibition of metallic corrosion using Ficus extracts, Port Electrochim Act, 24, 347-356.

[14] S.A.Umoren, I.B.Obot, E.E.Ebenso, P.C.Okafor, O.Ogbobe, E.E.Oguzie (2006) Gum arabic as a potential corrosion extract for aluminium in alkaline medium and its adsorption characteristics, Anti Corros Methods Mater, 53, 277-282.

[15] E.E. Oguz, A.I.Onuchukwu, P.C.Okafor, E.E.Ebenso (2006) Corrosion inhibition and adsorption behaviour of Occimum basiclicum extract on aluminium, Pigment Resin Technol., 35, 63-70.

[16] P.E.E.Oguz (2006) Adsorption and corrosion inhibitive properties of Azadirachta indica in acid solutions, Pig. Res.Technol., 35, 334-340.

[17] E.E.Oguzie (2007) Corrosion inhibition of aluminium in acidic and alkaline media Sansevieria trifasciata extract, Corros Sci, 49, 1527-1539.

[18] E.E.Ebenso, N.O.Eddy, A.O.Odiongenyi (2008) Corrosion inhibitive properties and adsorption behavior of ethanol extract of Piper guinensis as a green corrosion extract for mild steel in $\mathrm{H}_{2} \mathrm{SO}_{4}$, Afr J Pure Appl Chem, 11, 107-115.

[19] P.C.Okafor, U.J.Ekpe, E.E.Ebenso, E.M.Umoren, K.E.Leizou (2005) Inhibition of mild steel corrosion in acidic medium by Allium sativum extracts, Bull Electrochem, 21, 347-352.

[20] P.C.Okafor, U.J.Ekpe, E.E.Ebenso, E.E.Oguzie, N.S.Umo, A.R.Etor (2006) Extract of Allium cepa and Allium sativum as corrosion extracts of mild steel in $\mathrm{HCl}$ solution, Trans SAEST, 41, 8287.

[21] P.C.Okafor, V.I.Osabor, E.E.Ebenso (2007) Ecofriendly corrosion extracts: inhibitive action of ethanol extracts of Garcinia kola for the corrosion of mild steel in $\mathrm{H}_{2} \mathrm{SO}_{4}$ solutions, Pigment Resin Technol, 35, 299-305.

[22] P.C.Okafor, E.E.Ebenso (2007) Inhibitive action of Carica papaya extracts on the corrosion of mild steel in acidic media and their adsorption characteristics, Pig.Res.Technol, 36, 134-140.

P.C.Okafor, M.E.lkpi, P.Uwah (2008) Extract action of Phyllanthus amarus extracts on the corrosion of mild steel in acidic media, Corros Sci, 50, 2310-2317.
[23] A.Singh, V.K.Singh, M.A.Quraishi (2010) Corrosion inhibition of low carbon steel in $\mathrm{CO}_{2}$-saturated solution using Anionic surfactant, Advanc. in Appl. Sci. Res., 3(4), 811-824.

[24] F.Bentiss, M.Traisnel, N.Chaibi, B. Mernari, H.Vezin, M.Lagrenee (2002) 2,5-Bis (nmethoxyphenyl)-1,3,4-oxadizoles used as corrosion extracts in acidic media: correlation between inhibition efficiency and chemical structure, Corros. Sci., 44, 2271-2289.

[25] A.S.Fouda, M.Abdallah, R.A.El-Dahab (2010) Some quinazoline derivatives as corrosion extracts for copper in $\mathrm{HNO}_{3}$ solution, Desalin. And Water Treatm., 22, 1-9.

[26] E.Popova, S.Sokolova, S.Raicheva, M.Christov (2003) 2,5-Disubstituted 1,3,4-Oxadiazole Derivatives as Effective Extracts for the Corrosion of Mild Steel, In $2 \mathrm{M} \mathrm{H}_{3} \mathrm{PO}_{4}$ Solution, Corros. Sci., 45, 33-45.

[27] A.S.Fouda, A.Al-Sarawy, F.S.Ahmed, H.M.ElAddasy (2011) Effect of $\beta$-Blocker Extracts on Aluminum Corrosion, J. Korean Chem. Soc, 55(2), 268-278.

[28] M.K.Gomma, M.H.Wahdan (1995) Enaminonitrile derivatives as corrosion extracts for Cu10Ni alloy in $0.5 \mathrm{M} \mathrm{HCl}$ solutions, D. Pharm. Chem., 39, 209-213.

[29] J.Marash (1988) Advanced Organic Chemistry, $3^{\text {rd }}$ ed., Wiley Eastern, New Delhi.

[30] A.S.Fouda, F. El-Taib Heakal, M.S. Radwan (2009) Density Functional Theory (DFT) Studies on Sulfa Dimedine Azo Derivatives as Green Extracts for CSteel in $0.5 \mathrm{M} \mathrm{H}_{3} \mathrm{PO}_{4}$ Solutions, J. Appl. Electrochem., 39, 391-402.

[31] I.A.Ammar (2011) Thermodynamic and quantum chemistry study for dimethylol-5- methyl hydantoin and its derivatives as corrosion extracts for CSN-80 in raw water (cooling water system), J. Mater. Environ. Sci., 2 (2), 128-147.

[32] A.S.Fouda, A.M.Eldesoky, M.A.Elmorsi, M.Y.El Sheik, I.A.El Said (2014) Benzamide, acetamide and acrylamide as Corrosion extracts for $\mathrm{CS}$ in $\mathrm{HCl}$ solutions, Int. J. of Advanc.Res., 2 (2), 4-24.

[33] O.Benali, L.Larabi, S.M.mekelleche, Y.Harek (2006) Corrosion Inhibition of Mild Steel by 4- Allyl-5pyridin-4-yl-4H-1,2,4-triazole-3-thiol, J. Mater. Sci., 41, 7064-7073.

[34] P.Baradlai, J.H.PotgPter, W.O.Barnard, L.Tomcsanyi, K.Varga (1995) Study of Pitting Resistance of Duplex Stainless Steel Weldment Depending on the Si Content, Mater. Sci. Forum, 759, 185-188.

[35] A.K.Mohamed, H.A.Mostafa, G.Y.El-Awady, A.S.Fouda (2000) Inhibition Effect of N, N'Dimethylaminoethanol on the Corrosion of Austenitic Stainless, Steel Type 304 in $3 \mathrm{M} \mathrm{H}_{2} \mathrm{SO}_{4}$, Electrochim. Acta, 18, 99-106.

[36] S.A.Ali, H.A. Al-Muallem, M.T.Saeed, S.U.Rahman (2008) Quantum Chemical Study of 2Mercaptoimidazole, 2-Mercaptobenzimidazole, 2Mercapto-5-Methylbenzimidazole and 2- Mercapto5-Nitrobenzimidazole as Corrosion Extracts for Steel, Corros. Sci., 50, 664-678. 
[37] T.Tsuru, S.Haruyama, B.Gijutsu (1978) Corrosion Inhibition Performance of 3,5-Diamino- 1,2,4triazole for Protection of Copper in Nitric Acid Solution, J.Jpn. Soc.Corros. Eng., 27, 573-581.

[38] E.Kamis (1990) The effect of temperature on the acidic dissolution of steel in the presence of extracts corrosion, Int. J. of Advance. Sci Tech Res., 46, 476-484.

[39] S.S.A.El-Rehim, M.A.M.Ibrahim, K.F.Khaled (1999) 4-Aminoantipyrine as an extract of mild steel corrosion in $\mathrm{HCl}$ solution, J. Appl. Electrochem., 29, 593-599.

[40] T.T.Bataineh, M.A.Al-Qudah, E.M.Nawafleh, N.A.F.Al-Rawashdeh (2014) Sinapis Alba Extract as Green Corrosion Extract for aluminum in Alkaline, Media, Int. J. Electrochem. Sci., 9, 3543 - 3557.

[41] A.K.Maayta, N.A.F.Al-Rawashdeh (2004), Inhibition of acidic corrosion of pure aluminum by some organic compounds, Corros. Sci. 46, 1129-1140.

[42] A.Khadraoui, A.Khelifa, H.Boutoumi, H.Hamitouche, R.Mehdaoui, B.Hammouti , S.S. AlDeyab (2014) Adsorption and Inhibitive Properties of Ruta chalepensis L. Oil as a Green Extract of Steel in $1 \mathrm{M}$ Hydrochloric Acid Medium, Int.J.Electrochem. Sci., 9, 3334 - 3348.

[43] A.S.Fouda, A.M.El-desoky, D.M.Ead (2013) Anhydride Derivatives as Corrosion Extracts for CS in Hydrochloric Acid Solutions, Int. J. Electrochem.Sci., 8, 8823 - 8847.

[44] O.Benali, M.Ouazene (2011) Inhibition Effect of 3bromo-2-phenylimidazol $[1,2-$ a]pyridine towards C38 Steel Corrosion in $0.5 \mathrm{M} \mathrm{H}_{2} \mathrm{SO}_{4}$ Solution, Arab. J. Chem., 4, 443-448.

[45] K.K.Al-Neami, A.K.Mohamed, I.M.Kenawy, A.S Fouda (1995) Dimethyl Pyrimidine Derivatives as Corrosion Extracts for CSin Hydrochloric Acid Solutions, Monatsh. Chem., 126, 369-376.
[46] S.S.Abd El-Rehim, M.A.M.Ibrahim, K.F. Khaled (2013) Chemical and Electrochemical Investigations of L-Arginine as Corrosion Extract for Steel in Hydrochloric Acid Solutions, J. Appl. Electrochem., 8, 1409-1421.

[47] R.Rosliza, W.B. Wan Nik, H.B.Senin (2008) Comparative study of corrosion inhibition of aluminium alloy of type AA3003 in acidic and alkaline media by Euphorbia hirta extract, Mater. Chem. Phys., 107, 281-288.

[48] L.Larabi, O.Benali, Y.Harek (2007) Inhibition Effect of 3-bromo-2 phenylimidazol $[1,2-\alpha] p y r i d i n e$ towards $\mathrm{C} 38$ Steel Corrosion in $0.5 \mathrm{M} \mathrm{H} \mathrm{H}_{2} \mathrm{SO}_{4}$ Solution, Mater. Lett., 61, 3287-3291.

[49] L.Larabi, Y.Harek, O.Benali, S.Ghalem (2005) Application of Some Oligopolymers as Effective Corrosion Extracts for Mild Steel in $1 \mathrm{M} \mathrm{HCl}$ : Gravimetric,Thermodynamic and Electrochemical Analysis ,Prog. Org. Coat., 54, 256-262.

[50] E.M.Sherif, R.M.Erasmus, J.D.Comins (2006) Corrosion of copper in aerated acidic pickling solutions and its inhibition by 3-amino-1,2,4-triazole5-thiol, Colloid Int.Sci., 306, 96-104.

[51] S.A.Umoren, M.M.Solomon (2013) Kinetics of Corrosion Inhibition of Aluminum in Acidic Media by Water-Soluble Natural Polymeric Pectates as Anionic Polyelectrolyte Extracts, Materials, 6, 2436-2451.

[52] S.Ramachandran, M.Tsai, M.Blanco, H.Chen, W.A.Tang (2008) Langmuir, Molecular simulation, quantum chemical calculations and electrochemical studies, inhibition of mild steel by triazoles, Electr. Acta, 53, 3484-3492.

[53] G.Avci (2008) The Inhibition of Mild Steel Corrosion in $1 \mathrm{~N} \mathrm{HCl}$ by Imidazole Derivatives, Colloid Surf. A., 317, 730-736.

\section{IZVOD}

\section{ULOGA VODENIH OCIMUM BASILICUM EKSTRAKTA ZA PRAĆENJE INHIBICIJE KOROZIJE UGLJENIČNIH ČELIKA KORIŠĆENIH U SANITARNIM POSTROJENJIMA I NJIHOV UTICAJ NA Escherichia coli}

Efekat vodenog ekstrakta bilja Ocimum basilicum je testiran kao ekstrakt zelene korozije za CS (CS) na 3,5\% NaCl i 16 ppm $\mathrm{Na}_{2} \mathrm{~S}$. On ima odličnu efikasnost inhibicije (\% p) od oko 88\%, pod merenja smanjenja gubitka težine, potentiodinamičke polarizacije, elektrohemijske impedanse (EIS) i elektrohemijske frekvencije modulacije (EFM). Povećanje koncentracije ekstrakta dovodi do povećanja u \% P. Adsorpcija ekstrakta na CS površini prati Langmuirovu adsorpcionu izotermu sa fizičkom adsorpcijom na površini metala. Analiza EDKS i SEM potvrđuje da taloženje ekstrakta na metalnu površinu smanjuje reakciju korozije. Biološki test ekstrakta na Escherichia Coli kulture pokazuje da nema nikakvog uticaj na biološku aktivnost Escherichia coli i može se bezbedno primeniti bez štetnog efekta na sanaciju postrojenja.

Ključne reči: Ocimum Basilicum, EDX -SEM, sanitarna postrojenja, Escherichia coli.

Naučni rad

Rad primljen: 18. 07. 2016.

Rad prihvaćen: 22. 08. 2016.

Rad je dostupan na sajtu: www.idk.org.rs/casopis 